Rev. Bras. Saúde Prod. Anim., Salvador, v.14, n.2, p.382-395 abr./jun., 2013 http://www.rbspa.ufba.br ISSN 15199940

\title{
A new approach about the digestion of fibers by ruminants
}

\author{
Uma nova abordagem sobre a digestão de fibras por ruminantes
}

\author{
MOREIRA, Leonardo Marmo ${ }^{1,3 *}$; LEONEL, Fernando de Paula ${ }^{1}$; VIEIRA, Ricardo \\ Augusto Mendonça ${ }^{2}$; PEREIRA, José Carlos ${ }^{3}$
}

\author{
${ }^{1}$ Universidade Federal de São João Del Rei, Departamento de Zootecnia, São João Del Rei, Minas \\ Gerais, Brasil. \\ ${ }^{2}$ Universidade Estadual do Norte Fluminense Darcy Ribeiro, Centro de Ciências e Tecnologias Agropecuárias, \\ Laboratório de Zootecnia e Nutrição Animal, Campo dos Goytacazes, Rio de Janeiro, Brasil. \\ ${ }^{3}$ Universidade Federal de Viçosa, Departamento de Zootecnia, Viçosa, Minas Gerais, Brasil. \\ *Endereço para correspondência: leonardomarmo@gmail.com
}

\section{SUMMARY}

The decisive role of metallic cations in the formation of supramolecular clusters involving lignin, cellulose, and hemi-cellulose and its relationship to energy losses in ruminants associated with fibrous feed resources is still not well understood. Indeed, interactions between lignin, cellulose and metallic cations generate highly stable clusters that significantly decrease the capability of cellulase to break bonds between sugar units in order to facilitate the absorption of a great quantity of cellulose, which is ingested by ruminants as forage. Furthermore, several metallic cations cannot be absorbed as a consequence of the formation of coordinated ligations with the oxygen atoms of the lignocellulosic cluster. The loss of lignocellulose-metal clusters by ruminants is responsible for a substantial waste of nutrients, which is a significant problem in animal science. Moreover, the chemical structure of these relevant supramolecular systems is poorly understood. In the present review, we discussed this topic in detail in reference to relevant literature from the chemical and animal sciences in order to analyze the perspectives associated with the improvement of nutritional absorption from feed resources by ruminants.

Keywords: cellulose, clusters, feed resources, lignin, metallic cations, ruminant

\section{RESUMO}

O papel decisivo de cátions metálicos na formação de cluster supramoleculares envolvendo lignina, celulose e hemi-celulose and sua relação a perdas energéticas em ruminantes associadas com fontes de alimentação fibrosas não é ainda bem compreendida. De fato, interações entre lignina, celulose e cátions metálicos geram clusters altamente estáveis diminuem significativamente a capacidade da celulase quebrar ligações entre unidades sacarídicas com o objetivo de facilitar a absorção de uma grande quantidade de celulose, a qual é ingerida por ruminantes na forma de forragem. Além disso, diversos cátions metálicos não podem ser absorvidos como uma conseqüência da formação de ligações coordenadas com os átomos de oxigênio do cluster lignocelulósico. A perda de clusters lignocelulósico-metálicos por ruminantes é responsável por um substancial desperdício de nutrientes, o que é um problema significativo em zootecnia. Ademais, a estrutura química destes relevantes sistemas supramoleculares é pobremente compreendida. No presente artigo, nós discutimos esse tópico em detalhes, em concordância com relevante literatura química e zootécnica, objetivando analisar as perspectivas relacionadas com a melhoria com a absorção nutricional a partir de fontes alimentares por ruminantes.

Palavras-chaves: celulose, clusters, fontes nutricionais, lignina, cátions metálicos, ruminante 


\section{INTRODUCTION}

Refining the dietary balance is an important way to optimize animal production. This progress has been most advanced in domesticated nonruminant species; however, progress in ruminants has been slower because of the significant modifying influence of rumen fermentation, the fiber requirement of these animals, and the typical amino acid imbalances observed in poor-quality fibrous diets. Therefore, rumen fermentation modifies the diet, and the ruminant dietary balance must also consider the fiber quality, which is not a nutritionally, chemically or physically uniform material, as well as rumen microbial requirements (Van SOEST et al., 1991).

Rumen is responsible for the digestion of 60 to $90 \%$ of the cellulose and hemicellulose in the gastrointestinal tract, depending on the lignification of the forage. This process occurs because the presence of lignin provokes an interaction with carbohydrate fractions to form a type of supramolecular net that precludes the disruption of chemical bonds by the enzymatic complexes produced by ruminant microorganisms.

Energetic losses associated with clusters formed from lignin, cellulose, and hemicellulose constitute an academic challenge for several research groups worldwide. Animal scientists and biochemists have developed several studies focused on the elucidation of the molecular structure and molecular mechanisms underlying the formation and structural arrangement of clusters involving cellulose, hemicellulose and lignin. Chapple \& Carpita (1998) posited several questions about all aspects of cell wall synthesis and structure, including lignin and polysaccharide biosynthesis, to establish a better understanding of the complexity of the supramolecular arrangements formed with these biopolymers. In fact, lignified plant cell walls are formed by the successive deposition of these cell wall polymers, which are physically and chemically bound to each other in a biochemically regulated manner. This biosynthetic mechanism is an important factor that determines the ultrastructure of the lignified plant cell wall and ultimately determines their physical and chemical properties.

The nutritive potential of carbohydrates depends on the digestive actions of rumen microorganisms to cleave glycosidic bonds in the plant cell walls and the bonds between these compounds and other substances. Therefore, the nutritional chemistry of carbohydrates is largely a description of the degradation of structural and nonstructural carbohydrates and the factors that provoke their availability to animal and microbial digestion (Van SOEST et al., 1991). In the following sections, the chemical and biochemical properties of cellulose, hemicellulose and lignin will be presented to clarify their cluster formation mechanisms.

\section{LIGNIN}

Lignin (or "lignen") is a chemical compound characterized by a large and complex molecular structure, which is most commonly derived from wood, and is also an integral part of the secondary cell walls of plants and some algae. Lignin is a cross-linked racemic macromolecule with molecular masses in excess of $10,000 \mathrm{u}$. It is relatively hydrophobic and aromatic. Its degree of polymerization in nature is difficult to measure because it is fragmented during extraction and the molecule consists of various types of substructures that appear to repeat in a random manner. Different types of lignin have been 
described depending on the isolation process.

The term "lignin" was introduced in 1819 by de Candolle and it is derived from the Latin word "lignum", which means wood. It is one of the most abundant organic polymers on Earth and is exceeded in abundance only by cellulose. It makes up $30 \%$ of non-fossil organic carbon, and constitutes a quarter to a third of the dry mass of wood. Lignin is an unusual biopolymer because of its chemical heterogeneity and lack of a defined primary structure. Its most commonly known characteristic is its strengthening function in the wood (xylem cells) of trees. Global lignin production is approximately 1.1 million metric tons per year and is used in a wide range of low volume niche applications in which the form but not the quality is important.

Lignin plays a crucial role in conducting water within plant stems. The polysaccharide components of plant cell walls are highly hydrophilic and thus permeable to water, whereas lignin is more hydrophobic. The crosslinking of polysaccharides by lignin is an obstacle for water absorption to the cell wall. Thus, lignin makes it possible for the plant's vascular tissue to efficiently conduct water. Ligations between polysaccharides and lignin should favor the formation of clusters that tend to preclude the attack of enzymes produced by ruminal microorganisms on the glycosidic bonds between sugar monomers that constitute biopolymers hemicellulose and cellulose.

There are three monolignol monomers, and they are methoxylated to various degrees, namely $p$-coumaryl alcohol, coniferyl alcohol, and sinapyl alcohol.

\section{CELLULOSE}

Cellulose is a long-chain polysaccharide with $\left(\mathrm{C}_{6} \mathrm{H}_{10} \mathrm{O}_{5}\right) \mathrm{n}$ as its molecular formula. The molecular structure of cellulose is formed by a ligation between $\beta$-glucose molecules through $\beta$ 1,4-glycosidic bounds. Its complete hydrolysis generates free glucose molecules. Once this biopolymer is broken down to single monomers (into glycose), its molecular mass is variable, with a minimum value of $n=200$ (typically 300 to 700 monomeric units; in some cases approximately 7000 monomers). Cellulose has a linear and fibrous molecular structure with several hydrogen bonds between the hydroxyl groups of the parallel chains. Furthermore, many water molecules interact with the hydroxyl groups of its molecular structure. This spatial arrangement decreases the chemical permeability of the aqueous solvent molecules to cellulose chains, and for this reason, the macromolecule becomes highly insoluble and generates compact fibers that constitute the plant cell walls. Cellulose is one of the principal compounds of the plant cell wall (approximately $33 \%$ of the plant's mass), together with hemicelluloses, lignin and pectic substances. It was first isolated and characterized by the French chemist Anselme Payen in 1838.

\section{INTERACTIONS BETWEEN CELLULOSE, HEMI-CELLULOSE, AND LIGNIN}

Aman (1993) claimed that the intra- and intermolecular hydrogen bonds are decisive for producing a regular crystalline arrangement of the glucan chains, resulting in distinct $\mathrm{x}$-ray diffraction patterns, and they control both the physical and chemical 
characteristics of cellulose. The aggregates are composed of highly ordered crystalline and noncrystalline regions. Together with hydrogen bonds, the van der Waals interactions make an important contribution to maintaining the supramolecular aggregate. However,the metallic cation contribution must also be considered to obtain a better understanding of the high level of chemical stability in lignin-cellulose aggregates.

In agreement with Van Soest et al. (1991), the most important feed characteristic besides particle size to net rumen buffering is the buffering capacity of the feed. This property depends on the cation exchange ability of the fiber and, to some extent, on the fermentation of protein to ammonia. Ion-exchangeable groups within plant cell walls include carboxyl, amino, free aliphatic hydroxyls, and phenolic hydroxyls, all of which have some binding affinity for metal ions (Van SOEST et al., 1991). Thus, the surface properties for fiber, hydration, and cation exchange capacity are interrelated and may be associated with short digestion lag times and rapid rates of cell wall digestion. Microbes that have negatively charged cell walls "recognize" fibrous particles through their exchangeable surface and form attachments that require divalent cation ligands (probably magnesium). The cation exchange capacity is the ability of a fiber to bind (adsorb) metal ions to its surface in much the same way that clay minerals are able to hold cations in soil. The exchange serves as a bank, exchanging $\mathrm{K}^{+}, \mathrm{Ca}^{2+}, \mathrm{Na}^{+}$, and $\mathrm{Mg}^{2+}$ with $\mathrm{H}^{+}$when the $\mathrm{pH}$ drops, and the bank recharges when new cations become available as saliva and ingesta are mixed (Van SOEST, 1991).

Interestingly, there are several systems for measuring cation exchange in plant cell walls. For example, lithium is weakly bound, and variability is encountered in the washing procedures used for removing unbound lithium. Calcium and barium proved unsatisfactory because of sulfate interference. With regards to $\mathrm{Cu}^{2+}$, the interaction stability is more efficient at $\mathrm{pH} 3.5$ and is unstable at higher $\mathrm{pH}$ values. Copper is attracted by unionized amino groups, for which rare earth elements have little affinity. Both $\mathrm{Cu}$ and $\operatorname{Pr}$ have high affinities for phenolic groups, and their exchange values have high correlations with the lignin content. The strongest binding rare earth ions (praseodymium and neodymium) have been identified (Van SOEST et al., 1991).

In this context, it is important to note that cellulose can effectively coordinate heavy metal cations, such as $\mathrm{Cu}^{2+}$, to generate stable complexes that can be applied in Materials Engineering and other areas to improve the physicochemical and biological properties of materials of, for example, paper. In fact, Basta \& El-Saied (2008) demonstrated that using carboxymethyl cellulosecopper complexes [CMC-Cu(II)] as paper additives enhances the strength of wood pulp paper sheets, and depends on the copper salt anion and the $\mathrm{pH}$ value during the preparation process. The best polymer complex is that produced by using copper sulfate as the source of a copper ion, at $\mathrm{pH}$ 5.4. In addition, incorporating the $\mathrm{CMC}-\mathrm{Cu}$ (II) complexes with wood pulp provides thermal stability, fire retardancy, biological resistance, magnetism, as well as durability to paper sheets. Furthermore, the lignin-cellulose resinous material or alkali metal lignin-cellulose resinous products, which also influence the stability interactions between alkali metals and lignin-cellulose resins, may be used as an adhesive to produce plywood, laminates, and fillers and for reaction with aldehydes, aminoplasts, phenoplasts, epoxides, ketones, furfuryl alcohol, amines, isocyanates, polyamines, 
polyisocyanates, mono- and polysubstituted organic compounds to produce useful resins to use as adhesives, laminates, coating agents, molding agents and foams (BLOUNT, 2004).

Several studies have been focused on the employment of lignin-cellulose systems to capture heavy metals to eliminate metallic cations that are toxic to human and animal health (AHMED, 2011). The utility of common wood sawdust in removing heavy metal ions from wastewater has been examined (AHMED, 2011). Wood sawdust, a solid waste product of mechanical wood processing, can be used as a low cost heavy metal adsorbent, largely because of its lignocellulosic composition. It is mainly composed of cellulose (45-50\%) and lignin (23-30\%), both of which have the capacity to bind metal cations because of the hydroxyl, carboxylic and phenolic groups present in their structures . Cellulosic biomaterials enhance the adsorptive capacity for metal ions when covalently loaded with specific dyestuffs. Therefore, there are different applications for different research fields using modified wood sawdust for the removal or recovery of different metal ions from aqueous solutions (PEREIRA et al., 2007).

The use of citric acid solution, for example, is effective for the chelation reaction (NORMAN \& EARNSHAW, 1997) between carboxyl groups $(-\mathrm{COOH})$ and metallic impurities contained in husks, and it results in the removal of these impurities, such as $\mathrm{Na}^{+}, \mathrm{K}^{+}, \mathrm{Ca}^{2+}, \mathrm{Mg}^{2+}, \mathrm{Fe}^{2+}$ or $\mathrm{Fe}^{3+}, \mathrm{Cu}^{+}$ or $\mathrm{Cu}^{2+}$, etc., as metal complexes from rice husks during the leaching treatment (UMEDA, 2010). This case demonstrates the ability of the hydroxyl and carbonyl groups to coordinate with metallic cations, including heavy metal cations, which can also occur in other organic functions with hydroxyl groups and oxygen atoms, and not only in carboxylic acids. Indeed, hemi-cellulose and cellulose are carbohydrates, i.e., polyhydroxy aldehyde chains, which present donor atoms, such as oxygen atoms, and donor groups, such as hydroxyls and carbonyls.

Lignins are phenolic polymers of the cell wall, and they form the second most abundant group of plant biopolymers, after cellulose (BOUDET, 1998). It is important to note that lignin is unusual in comparison to other abundant natural polymers because of its low degree of order and high degree of structural heterogeneity (RALPH, 1998). Lignin has always been considered an enigma in the natural world (HARKIN, 1973). It is a polymer with no defined structure, no regularly repeating sequences of any length, and an illdefined size. Although lignins are one of the most abundant macromolecules in plant tissues, much of this renewable biomass resource is wasted during papermaking and sugar production processes because it is simply burned and used as an energy source. Various efforts have been made to better understand the relationships between the structure and properties of these macromolecules to identify more efficient applications. Lignin macromolecules are made of phenyl-propane units (C9 units) with different chemical groups linked to their structure according to the plant species (MARTINS, 1998). It seems that the plant system is similarly adaptable with respect to lignin. For example, the major lignin building block is a simple natural chemical called coniferyl alcohol (RALPH, 1998). It is important to note that lower amounts of lignin in a plant are associated with a more digestible character (RALPH, 1998).

For these reasons, the hydrogen bonds and van der Waals interactions make important contributions to maintaining different types of vegetal fiber clusters in a united arrangement. However, the complexity and compaction of the 
clusters formed by lignin, cellulose and hemicellulose is very significant, which suggests there are other possible interactions that stabilize the clusters. Indeed, the presence of anionic sites on cellulose and hemicellulose (the amphoteric character of the hydroxyl groups, which are present in high numbers in the carbohydrates, can produce the anionic sites through acid dissociation (proton liberation) should decrease the contribution of apolar contacts, which is the case for van der Waals interactions. In any case, a great number of extreme chemical treatments is necessary to disrupt this complex tridimensional arrangement, leading to the inference that associations between lignin, cellulose and hemicellulose could include contributions that are not usually considered in most studies on this topic.

An association with lignin helps maintain the reservoir of buffering exchangeable cations in the rumen. Lignin is also associated with cell wall carbohydrate crosslinking and inhibits particle size breakdown by rumen organisms, so it is an essential feature of coarse fiber. It can have positive functions in the rumen in contrast with its dominant role in lowering digestibility. There is probably a lignin requirement for the rumen, but it cannot be so high as to limit the availability of dietary energy (Van SOEST et al., 1991).

A fundamental pre-requisite to understanding this complex question consists in the molecular structures of lignin, cellulose and hemi-cellulose, which present a great number of sites with available electronic pairs. These sites are denominated "Lewis bases" and are constituted by donor electronic pairs. These electrons are found mainly in oxygen atoms, which are present in the molecular structures of lignin, cellulose and hemi-cellulose, and they are very accessible to electron pair receptors ("Lewis acids"). Considering that mineral elements are relevant forage components, it is possible to infer that some cationic ions could act as "Lewis acids" to the great number of "Lewis bases" found in lignin, cellulose, and hemi-cellulose.

Martins et al. (2008) studied ultrathin lignin film as a potential transducer in sensing applications involving heavy metal ions to exploit the sensitivity of nanostructured lignin films to metallic ions $\left(\mathrm{Cu}^{2+}, \mathrm{Cd}^{2+}\right.$ and $\left.\mathrm{Pb}^{2+}\right)$. Their results revealed that each lignin is sensitive to specific individual ions $\left(\mathrm{Pb}^{2+}, \mathrm{Cu}^{2+}\right.$, and $\mathrm{Cd}^{2+}$ ), anticipating a potential application in sensing units with high specificity for the recognition of heavy metal ions. For instance, both impedance spectroscopy and electrochemistry measurements were used to distinguish different concentrations of $\mathrm{Cu}^{2+}$ in aqueous solutions. Finally, FTIR spectroscopy suggested an interaction between the phenyl groups of the lignin and the metallic ions, which directly correlated to the use of lignin as a transducer in sensor applications.

Considering that a lignin monolayer can effectively bond heavy metal ions, a great quantity of lignin could generate a great number of stable ligations with metallic cations, mainly heavy metal ions, as a function of the presence of low energy $d$ orbitals that support 4,5 and frequently 6 sites of a coordination bond with electron pair donors, which can act as ligands of the respective coordination center. In fact, this type of study was motivated by the wellestablished knowledge that lignins have a strong affinity to heavy metals (PEREIRA, 2007).

In natural environments, many sorbent phases are able to absorb metal ions, such as metal oxides and oxyhydroxides, clay minerals, and organic matter. The sorbent phase plays a significant role in the type, strength, and reversibility of metal complex formation, and thus 
determines if the metal ion is immobilized or leached. This is why many studies have established the importance of independent surfaces in the retention of metals, such as organic matter, which includes lignocellulosic substrate and humic substances, goethite, gibbsite, and silica (FLOGEAC et al., 2005). Heavy metal cations, such as $\mathrm{Fe}^{3+}, \mathrm{Cr}^{3+}$ and $\mathrm{Mn}^{2+}$, are examples of metallic cations that are bound by these natural chemical environments. For example, iron and manganese are employed in an octahedral environment, which is coherent with their hexacoordinate characters (FLOGEAC et al., 2005).

Interestingly, studies focused on lignin model systems have demonstrated the effective interactions between metallic coordination compound centers and lignin-like units, such as the watersoluble Co-sulfosalen complex that constitutes an active catalyst with molecular oxygen in the oxidation of both phenolic and non-phenolic lignin model compounds (SIPPOLA, 2003). Indeed, simple complexes can facilitate the oxidative degradation of lignin model compounds (HUYNH, 1986).

\section{THE SURFACE AREA OF THE SUPRAMOLECULAR CLUSTER OF CELLULOSE, HEMI-CELLULOSE AND LIGNIN AND THE COMPACTION INFLUENCE OF THE METALS}

The complex process of chewing is first aimed at grinding food ingested by the ruminant, and its subsequent objective is to increase the surface area presented by the supramolecular net involving cellulose, hemi-cellulose and lignin. The enzymatic action developed by rumen microorganism cellulase has a higher likelihood of having direct contact with biological macromolecules. Thus, the higher surface area of the supramolecular net generated by the physical and chemical actions of the digestive process favors direct contact between cellulose and cellulase, allowing its occurrence with lower stereochemical difficulty for the enzymatic catalysis of bond breakage between the cellulose monomers in monosaccharides as a function of the higher direct physical contact between cellulose and cellulase.

In this context, it is important to mention that the higher number of chemical ligations as well as ionic and hydrophobic interactions involving the sites of the macromolecules that constitute the supramolecular net will result in a lower supramolecular net in the cluster (net of cellulose, hemicellulose and lignin). Thus, the decrease in the number and intensity of these contacts would imply a decrease in the efficiency of these interactions, thereby increasing the surface area of the supramolecular cluster, and favoring the enzymatic action of cellulose. Consequently, this process tends to generate a higher energetic gain from the polysaccharide cellulose and hemicellulose ingested by the ruminant.

Considering that the presence of metallic ions generates more chemical interactions and bonds, the compaction level of the cluster tends to be higher with a significant presence of metallic cations. In fact, the medium distance between the atoms would be lower with a higher number of coordinated covalent bonds between the donor sites of cellulose, hemi-cellulose and lignin and the metals, implying a higher compaction of the cluster and a probable lower surface area.

An understanding of these interactions can be an important pre-requisite for a higher energetic gain from carbohydrates as well as a higher physiological absorption of the metallic cations. This understanding can be a relevant factor in planning animal diets, 
with the aim of getting a higher nutritional gain from the food ingested by the animal, which can consequently decrease the time of physical development for each individual, and also decreases the economic loss and makes some strategies of animal nutrition more productive in ruminants.

In this way, nutrition strategies involving concentrates, forages and salts (especially metallic salts) could be analyzed with the purpose of improving resources with respect to the nutrition administration and/or the physiological/energetic gain associated with individuals. This inference is possible because a quantity of metallic salts significantly above the limit for animal productive performance could mean a significant economic loss without necessarily generating a representative physiological gain. It is possible, for example, that quantities of salts concomitantly administered to ingested forage could present low absorption values and decrease the energetic gain from cellulose. In this case, metallic cations of predominant hexacoordinate character would have, when present in great quantities, a higher negative impact on the process of carbohydrate absorption, which would also be intrinsically related to the low absorption of these metals. Indeed, a higher quantity of metals generates a higher number of coordinated covalent bonds and, consequently, a higher compaction of the supramolecular net. Therefore, this treatment generates a lower surface area and lower enzymatic breakage, producing a lower nutrition gain with the absorption of ingested nutrients. On the other hand, if a great loss of metallic cations is unavoidable as a function of the lignin-cellulose cluster formation, it is possible to infer that, in some contexts, it would be an interesting alternative to increase the quantity of metals in the diet, considering the significant loss of metallic cations as coordination centers in the supramolecular clusters.

In this context, it is possible that strategies involving time intervals between the administration of metallic salts and forages/nutrition supplements could favor the occurrence of improved metallic ion absorption levels as well as carbohydrates, such as the monosaccharides originating from the chemical breakage of cellulose and hemi-cellulose.

\section{THE MOST RELEVANT METALLIC CATIONS IN RUMINANT NUTRITION}

The inorganic elements that are essential ruminant nutrients at higher concentrations (macroelements) are calcium, phosphorus, magnesium, chlorine, sodium, sulfur and potassium. The principal inorganic elements that are essential to ruminants at a lower concentration (microelements) are iron, copper, manganese, iodine, zinc, cobalt, selenium, chrome and nickel (ZANETTI, 2001).

The relationship between dietary mineral concentrations and animal health is very different for essential versus nonessential minerals (NRC, 2005). For essential minerals, increasing the amounts of a mineral in the diet is highly beneficial up to a point (to meet a requirement), beyond which additional amounts have little additional value. At some point (the maximum tolerable level), higher dietary concentrations become detrimental to animal health. In the case of nonessential minerals, low levels are tolerated without detrimental effects. At some point, higher concentrations become harmful (NRC, 2005).

It is important to note that magnesium, calcium, potassium, zinc, copper and iron, among others, have special relevance with regards to the mineral 
constitution of several types of forages and are employed in animal science to improve the productivity associated with ruminants. These minerals are commonly present in significant concentrations in the nutritional sources provided to animals. Indeed, $\mathrm{Zn}^{2+}, \mathrm{Fe}^{2+}$ and $\mathrm{Fe}^{3+}$ are examples of cationic ions that can act as "Lewis acids" to form covalent bonds, which are coordinated bonds, with the several oxygen atoms of lignin, cellulose and hemi-cellulose. Therefore, in addition to the mutual loss of metallic cations (that are inherent to the chemical composition of the plants ingested by the animal) and the cellulose and hemicellulose that are the principal energy sources for ruminants, there is a very relevant nutritional loss. This loss corresponds to the metals present in the several nutritional supplements that are provided to the animals, considering their specific nutritional needs to favor a shorter developmental period.

\section{METAL SUPPLEMENTATION IN RUMINANT NUTRITION}

One of the biggest problems in mineral studies is the interactions between different elements that can act synergistically, such as calcium and phosphorus, or antagonistic interactions, such as those of copper and molybdenum. These interactions are important because the suitable level of copper in forage cannot be sufficient if the molybdenum is present in higher amounts (ZANETTI, 2001) when the level of molybdenum is lower than $3 \mathrm{ppm}$; 10ppm of copper would be sufficient. However, if the molybdenum is present at higher levels, the copper requirement should increase to $20 \mathrm{ppm}$.

The positive effects of metal supplementation in cattle is generally the decisive factor in their physiological development. Nevertheless, there are a great number of cattle in Brazil that do not receive any metallic supplementation (there is a common salt that is basically sodium chloride (ZANETTI, 2001).

In Colombia, it was verified that the complete mineral mixture improved all the development parameters under study when compared with a supplement made only with common salt, i.e., with sodium chloride.

Although the extreme deficiencies are more easily identified, they are less widespread. The great problem with metallic deficiency in ruminant nutrition is mainly related to marginal deficiencies that, in spite of only lightly influencing a single animal (for a small decrease in the production of a unique individual), they can provoke great losses because of the large number of animals with mineral deficiencies (ZANETTI, 2001).

Considering the methodologies usually employed for the detection of mineral deficiencies, soil analysis can furnish some data, but hardly resolves this problem. On the other hand, forage analysis is a more interesting strategy, but it is necessary to provide a significant number of measurements with which to select the sample, mainly to avoid contamination and nonrepresentative materials with respect to the ingestion by the animal (ZANETTI, 2001). In spite of this trend, the more consistent knowledge regarding mineral salts does not mean the quantities that are effectively absorbed by the animal are known, and in this context, knowledge of the molecular structure of the lignin-cellulose cluster is fundamental for inferring the causes of some nutritional strategies, which can have a minimal effect on animal physiology. 
METALLIC CATIONS ACT AS COORDINATION CENTERS FOR LIGNIN-CELLULOSE CLUSTERS

It is possible to claim that several cationic ions (including metallic ions), which are usually present in most nutritional sources, act effectively as coordination centers for several electronic donor sites (oxygen atoms with their "free" electronic pairs). These ions then act as ligands for the coordination centers. In fact, some sites are neutral and other basic sites are negatively charged (anionic sites), thereby constituting distinct types of electronic donor sites.

Interestingly, coordination centers such as $\mathrm{Fe}^{2+}, \mathrm{Fe}^{3+}, \mathrm{Cu}^{+}$and $\mathrm{Cu}^{2+}$ often have six ligands ("number of coordination": 6), i.e., these metallic centers are frequently hexacoordinated centers. Therefore, each metallic center, such as $\mathrm{Fe}^{3+}$, could form six (6) bonds with different donor atoms, such as oxygen atoms, in its chemical neighborhood. $\mathrm{Zn}^{+2}$ is usually found in a tetracoordinated center ("coordination number": 4) because of the electronic configuration of its $d$ atomic orbitals $\left(d^{8}\right)$. In this way, the supramolecular system formed by lignin, cellulose and hemi-cellulose would generate various chelant regions to the metallic center that are stereochemically available in this molecular position, and it has the potential to form at least four coordinated covalent bonds.

The relative structural flexibility of lignin, cellulose and hemi-cellulose should favor the formation of a significant "coordination number" for each metallic center. In this case, the low degree of order and the high degree of heterogeneity that are common to lignin (RALPH, 1998) should favor a higher availability of different oxygen sites to coordinate with the various metallic cations, which are present in the same chemical medium. This coordination involves the so-called "macrocyclic effect" (that is, a type of "accentuated quelant effect"), which corresponds to structural stability and involves thermodynamic and kinetic effects in the coordination centers bound to at least three (3) donor sites for only one ligand. It is possible to infer the great difficult in any process for breaking these bonds. Furthermore, each metallic center can be coordinated by two, three or more different molecules. Indeed, the oxygen atoms of different macromolecules can be coordinated to the same cationic center. Consequently, the cationic centers would generate a complex chemical net, maintaining connections between different molecules, such as lignin, cellulose and hemi-cellulose.

It is important to note that, in agreement with the Pearson classification (the acid-base Pearson concept involves "hard" and "soft" acids and bases), oxygen is a predominantly "hard" base, which prefers "hard" acids with which to form stable bonds. In this way, ions with small ionic radii and high oxidation states should generate stronger ligations. These properties are common to several cations in forages. Indeed, these cations involve metals from the first transition series, which includes iron and zinc, and small metals, such as magnesium and calcium. Ions such as $\mathrm{Fe}^{3+}$ are considered "hard" acids by Pearson's classification, and $\mathrm{Fe}^{2+}$ is classified as a "borderline" acid.

It is interesting to note that an eventual bond disruption would be more plausible in a very acid medium, in which the protons could compete with the metallic centers for the Lewis bases. However, in the $\mathrm{pH}$ ranges most frequently present in rumen, that is, between $\mathrm{pH} \quad 6$ and 7 (in pasture systems) or between $\mathrm{pH} 5.8$ and 6.3 (in confinement systems), the low 
concentration of hydrogen ions is not enough to generate any significant loss of metallic coordination. In this way, a non-trivial coordination net would be a very decisive factor contributing to the loss of cellulose and hemi-cellulose in the rumen as well as the loss of mineral elements.

It is important to note that the various coordinations of each metallic cation in relation to the electronic donor sites (Lewis bases), which are predominantly oxygen atoms, generate a synergic effect on the formation of hydrogen bonds and van der Waals interactions. In other words, an increase in the number of metallic coordinations tends to favor the formation of a higher number of hydrogen bounds and van der Waals interactions involving the atoms of the cluster. In fact, the formation of a significant number of coordinations requires spatial proximity between the Lewis acid (metallic cation) and its respective Lewis bases. This proximity is maintained by coordinated bond formation, which tends to be highly stable, considering the potential number of ligations for each coordination center (up until 6 coordinations). Thus, the higher number of coordinations causes higher spatial proximity between the different atoms of hemicellulose, cellulose, lignin and other molecules present in the medium, such as water molecules. Subsequently, this higher spatial proximity generates a higher number of weak interactions because of the physical contacts between the atoms of only one macromolecule (intra-chain contacts), distinct macromolecules (inter-chains contacts) and between macromolecules and small molecules, such as $\mathrm{H}_{2} \mathrm{O}$. Over time, this higher number of hydrogen bonds and van der Waals interactions stereochemically favors the maintenance of the previous coordinations and the formation of novel coordinated covalent bonds, accentuating the bond nets between metallic cations, cellulose, hemicellulose, lignin and other small molecules present in the chemical medium. Therefore, this type of synergic effect tends to favor the formation of effective bond nets and is extremely difficult to disrupt because of the great number of interactions as well as the structural flexibility of the macromolecules.

The ligation between these carbohydrates and metallic cations would be an important souce ofenergy loss through the excretion of a great quantity of cellulose and hemicellulose, and would consequently decrease the ruminant mass gain. Moreover, this process would also be responsible for significant mineral element losses, accelerating the nutritional loss generated by the formation of clusters involving lignin, cellulose, hemicelluloses and metallic cations. Therefore, the complexation of cationic ions and fibers, such as lignin, cellulose and hemicelluloses, can be considered important in determining the nutritional loss of both, that is, the excretion of metallic ions and fibers. Furthermore, considering the physicochemical complexity and the great size of the respective supramolecular cluster, it is possible that other types of compounds are also present, such as proteins, which could be coordinated to the metallic center or simply interact electrostatically with the vegetal fibers. In fact, the large number of anionic sites can favor interactions with some protein sites, mainly the cationic sites of this type of zwitterionic biological macromolecule.

Thus, together with the influence of hydrogen bonds and van der Waals interactions, the decisive role of metallic ions should be considered to explain, at least partially, the formation of clusters by lignin, cellulose and hemicellulose. These interactions are relevant for forming strategies to 
improve the nutritional treatment of ruminants. In fact, understanding the structural characteristics of clusters involving vegetal fibers is fundamental to promoting subsequent studies aimed at decreasing the nutritional loss associated with the main nutritional procedures and the productivity of ruminant species. Interestingly, the cell wall constituents of feces from three faunated and three defaunated (without ruminal ciliate protozoa) cattle fed on sudangrass has been analyzed and provided different results (KASUYA, 2007). There was little difference in the digestibility of dry matter between the faunated and defaunated cattle. An analysis of fecal sugar residues revealed that the digestibilities of arabinose and galactose, as derived from pectic and hemicellulosic substances located within the compound middle lamella, were higher in the defaunated cattle than the faunated cattle $(\mathrm{P}<0.05)$, whereas the digestibilities of glucose and xylose, which were derived mainly from cellulose and xylan, were unchanged by the removal of protozoa (KASUYA, 2007).

The present review constitutes an exploratory analysis regarding the action of metallic cations on the nutritional loss of forages and rations. Nutritional methodologies must consider interactions between metallic cations and electron-donor sites (Lewis bases), which are found in great numbers in cellulose, hemi-cellulose and lignin. In this way, nutrition strategies should be evaluated to aim for a lower loss of forage. The determination of an optimum administration for different types of nutrients, including mineral salts, can be an interesting alternative for improving the physiological absorption of the fibers and the other components of the animal nutrition. Furthermore, the lignocellulosic species has attracted attention as a possible biofuel resource, including the microbial conversion of lignocellulose to hydrogen, which would be a fascinating way to provide a renewable energy source, and indicates the relevance of a better understanding of the chemical structure presented by these clusters (Le NGOC HUYEN, 2011; WANG, 2009).

\section{REFERENCES}

\author{
AHMED, S.A. Batch and fixed-bed \\ column techniques for removal of \\ $\mathrm{Cu}(\mathrm{II})$ and $\mathrm{Fe}(\mathrm{III})$ using carbohydrate \\ natural polymer modified complexing \\ agents. Carbohydrate Polymers, v.83, \\ p.1470-1478, 2011.
}

AMAN, P. Composition and Structure of Cell Wall Polysaccharides in forages. In: JUNG, H.G.; BUXTON, D.R.; HATTIELD, R.D.; RALPH, J. (Eds.). Forage Cell Wall Structure and Digestibility. Madison: ASA/CSSA, 1993. p.183-199.

BASTA, A.H.; El-SAIED, H. New approach for utilization of cellulose derivatives metal complexes in preparation of durable and permanent colored papers. Carbohydrate Polymers, v.74, p.301-308, 2008.

BLOUNT, D.H. Production of compounds, modified lignin, lignincellulose resinous compounds, carbon dioxide, carbohydrates and ethanol from biomass involves heating aqueous solution of alkali metal hydroxide and then heating biomass. United States patent US 2004121436A1, US6908995-B2, 5 Jan. 2001, 21 June. 2004.

BOUDET, A.M. A new view of lignifications. Trends in plant science, v.3, p.67-71, 1998. 
Rev. Bras. Saúde Prod. Anim., Salvador, v.14, n.2, p.382-395 abr.jun., 2013 http://www.rbspa.ufba.br ISSN 15199940

CHAPPLE, C; CARPITA, N. Plant cell walls as targets for biotechnology.

Current Opinion in Plant

Biotechnology, v.1, p.179-185, 1998.

FLOGEAC, K.; GUILLON, E.; APLINCOURT, M. Adsorption of several metal ions onto a model soil sample: Equilibrium and EPR studies.

Journal of Colloid and Interface Science, v.286, p.596-601, 2005.

HUYNH, V. Blomimetlc Oxidation of lignin model compounds by simple inorganic complexes. Biochemical And Biophysical Research Communications, v.139, p.1104-1110, 1986.

KASUYA, N.; WADA, I.; SHIMADA, M.; KAWAI, H.; ITABASHI, H. Effect of presence of rumen protozoa on degradation of cell wall constituents in gastrointestinal tract of cattle, Animal

Science Journal, v.78, p.275-280, 2007.

Le NGOC HUYEN, T.; QUENEUDEC T'KINT, M.; REMOND, C.; CHABBERT, B.; DHEILLY, R.M. Saccharification of Miscanthus $\mathrm{X}$ giganteus, incorporation of lignocellulosic by-product in cementitious matrix, Comptes Rendus - Biologies. v.334, p.837.e1-837.e11, 2011.

MARTINS, G.F.; PEREIRA, A.A.; STRACÇALANO, B.A.; ANTUNES, P.A.; PASQUINI, D.; CURVELO, A.A.S.; FERREIRA, M.; RIUL JUNIOR, A; CONSTATINO, C.J.L. Ultrathin films of lignins as a potential transducer in sensing applications involving heavy metal ions. Sensors and Actuators B, v.129, p.525-530, 2008.
NATIONAL RESEARCH COUNCIL NRC. Mineral tolerance of animals. 2 ed. Washington, DC.: The National Academies Press, 2005.

NORMAN, N.; EARNSHAW, A. Chemistry of the Elements, $2^{\text {th }}$ ed. Butterworth-Heinemann, Oxford, 1997.

PEREIRA, A.A.; MARTINS, G.F.; ANTUNES, P.A.; CONRRADO, R.; PASQUINI, D.; JOB, A.E.; CURVELO, A.A.S ; FERREIRA, M.; RIUL JUNIOR, A.; CONSTANTINO, C.J.L. Lignin from sugarcCane bagasse: extraction, fabrication of nanostructured films, and application. Langmuir, v.23, p.66526659, 2007.

POKROVSKI, G.S.; SCHOTT, J.; FARGES, F.; HAZEMANN, J-L. Iron (III)-silica interactions in aqueous solution: insights from X-rtay absorption fine structure spectroscopy. Geochimica and Cosmochimica Acta, v.67, p.35593573, 2003.

RALPH, J.; HATFIELD, R.D.; SEDEROFF, R.R.; MACKAY, J.J. Variations in lignin: what do recent studies on lignin-biosynthetic-pathway mutants and transgenics reveal about lignification. Madison, WI: US Dairy Forage Research Center, 1998. p.34-38.

SIPPOLA, V.O.; KRAUSE, A.O.I. Oxidation activity and stability of homogeneous cobalt sulphosalen catalyst Studies with a phenolic and a nonphenolic lignin model compound in aqueous alkaline medium. Journal of Molecular Catalysis A: Chemical, v.194, p.89-97, 2003.

UMEDA, J.; KONDOH, K. Highpurification of amorphous silica originated from rice husks by combination of polysaccharide hydrolysis and metallic impurities removal.

Industrial Crops and Products, v.32, p.539-544, 2010. 
Rev. Bras. Saúde Prod. Anim., Salvador, v.14, n.2, p.382-395 abr./jun., 2013 http://www.rbspa.ufba.br ISSN 15199940

VAN SOEST, P.J.; ROBERTSON, J.B.; LEWIS, B.A. Methods for dietary fiber, neutral detergent fiber, and no starch polysaccharides in relation to animal nutrition. Journal of Dairy Science, v.74, n.10, p.3583-3597, 1991.

WANG, A.; GAO, L.; REN, N.; XU, J.; LIU, C. Bio-hydrogen production from cellulose by sequential co-culture of cellulosic hydrogen bacteria of Enterococcus gallinarum G1 and Ethanoigenens harbinense B49.

Biotechnology Letters, v.31, p.13211326, 2009.
ZANETTI, M.A. Suplementação mineral para bovines de corte. In: SIMPÓSIO GOIANO SOBRE MANEJO E NUTRIÇÃO DE BOVINOS, 3., Goiânia. Anais... Goiânia: Congresso Brasileiro de Nutrição Animal, 2001. p.223-242.

Data de recebimento: $15 / 05 / 2013$

Data de aprovação: 27/06/2013 